\title{
Changes in Polyphenol Content of Olives Stored in Modified Atmospheres
}

\author{
R. Maestro, J.M. García, and J.M. Castellano \\ Instituto de la Grasa y sus Derivados-Consejo Superior de Investigaciones \\ Científicas, P.O. Box 1078, Seville 41012, Spain
}

Additional index words. Olea europaea, rancidity, olive oil, edible oil, oxidation

Coordinating olive (Olea europaea L.) harvest with oil extraction is difficult; thus, fruit are stored up to several weeks. Consequently, fruit suffer mechanical, physicochemical, and physiological alterations that lead to quality deterioration. Oils extracted from these damaged fruit are undesirable and must be refined, a process that raises costs and results in nutritional and market value losses.

Oils rich in polyphenols are quite resistant to rancidity (Vázquez et al., 1973); polyphenols disappear when the oil oxidizes (Chimi et al., 1988).

'Mission' table olives stored at $5 \mathrm{C}$ under $2 \%$ to $5 \% \mathrm{O}_{2}$ and $2.5 \%$ to $10.5 \% \mathrm{CO}_{2}$ maintained good quality for up to 10 weeks (Woskow and Maxie, 1965). Nevertheless, 'Manzanillo' exhibited $\mathrm{CO}_{2}$ injury when exposed to $5 \% \mathrm{CO}_{2}$ or more at the same temperature (Kader et al., 1990).

Siriphanich and Kader (1985) reported that atmospheres with high $\mathrm{CO}_{2}$ and low $\mathrm{O}_{2}$ inhibit vegetable tissue browning and decrease polyphenoloxidase activity. This activity is the main cause of polyphenol destruction in olives (Sciancalepore and Longone, 1984).

We, therefore, investigated changes in polyphenol content in olives stored under modified atmospheres (MAs) or in air in relation to the oil's resistance to oxidation.

Ripe 'Picual' olives grown in Seville, Spain, were picked from 20-year-old trees in early December. Random lots were sorted and matched for the different treatments,

Five storage conditions were tested: three MAs-20\% $\mathrm{O}_{2}+77 \% \mathrm{~N}_{2}+3 \% \mathrm{CO}_{2} ; 5 \% \mathrm{O}_{2}+$ $92 \% \mathrm{~N}_{2}+3 \% \mathrm{CO}_{2} ; 5 \% \mathrm{O}_{2}+94 \% \mathrm{~N}_{2}+<1 \%$ $\mathrm{CO}_{2}$; air at $5 \mathrm{C}$ and $90 \%$ to $96 \%$ relative humidity ( $\mathrm{RH})$; and one each in air at $5 \mathrm{C}$ or ambient temperature $(12 \pm 5 \mathrm{C}, 65 \%$ to $70 \% \mathrm{RH})$. MA storage conditions were maintained in sealed $60 \times 40 \times 40$-cm plastic containers. Fruit in air were kept in similar, but open, containers.

Four trays (one per sampling date), each containing $6 \mathrm{~kg}$ of fruit, were put in each container. Fruit were sampled after $0,15,30$, and 45 days of storage.

\footnotetext{
Received for publication 25 June 1992. Accepted for publication 26 Feb. 1993. We gratefully acknowledge the technical assistance of M. Caro Sánchez and M.J. Lazo Marvá. The cost of publishing this paper was defrayed in part by the payment of page charges. Under postal regulations, this paper therefore must be hereby marked advertisement solely to indicate this fact.
}

days of storage, polyphenol content decreased linearly throughout the storage period.

Keeping $\mathrm{CO}_{2}$ at $3 \%$ gave significantly $(P \leq$ $0.05)$ better polyphenol retention than storage in air at $5 \mathrm{C}$ by day 45 . Using high $(3 \%) \mathrm{CO}_{2}$ and low $(5 \%) \mathrm{O}_{2}$ resulted in the lowest polyphenol loss (significant at $P \leq 0.05$ ).

High $\mathrm{CO}_{2}$ was more effective than low $\mathrm{O}_{2}$; this result suggests that $\mathrm{CO}_{2}$ may act as an antagonist of $\mathrm{O}_{2}$ in polyphenol oxidation. The presence of an abnormally high $\mathrm{CO}_{2}$ concentration in the storage atmosphere likely results in an increased $\mathrm{CO}_{3}^{-2}$ ion concentration in the cell cytoplasm. This action decreases internal $\mathrm{pH}$ and hinders organic acid decarboxylation.

A combination of high $\mathrm{CO}_{2}$ and low $\mathrm{O}_{2}$ seems to inhibit polyphenoloxidase activity significantly and is the main cause of polyphenol destruction in olives.

\section{Literature Cited} (model 1400; Servomex Co.) for $\mathrm{O}_{2} \mathrm{C}$ tions for atmospheric composition were made by injecting pressurized $\mathrm{N}_{2}, \mathrm{CO}_{2}$, air, or a combination. Excess $\mathrm{CO}_{2}$ was corrected by bubbling the gas through $2 \mathrm{~N}$ aqueous $\mathrm{KOH}$.

Polyphenol extraction was carried out in triplicate, after pit removal, according to Vázquez et al. (1971).

Polyphenols were determined by Association of Official Analytical Chemists (AOAC) procedures (AOAC, 1970) and a modification of the procedure of Swain and Hillis (1959). Analyses were conducted in triplicate and results were expressed as milligrams of 4-hydroxy-phenyl-ethanol (tyrosol) per grams of pulp (dry weight).

Sample differences were determined by analysis of variance; mean separation was performed by LSD at $P \leq 0.05$.

Storage at $5 \mathrm{C}$ delayed the sharp decrease in polyphenol content compared to storage at $\approx 12 \mathrm{C}$ (Fig. 1 ). At $\approx 12 \mathrm{C}$, polyphenol content decreased between days 15 and 30 . In air at $5 \mathrm{C}$, there was a similar decrease, but only between days 30 and 45; thus, the lag phase during which polyphenol content fell slowly was prolonged.

Reducing $\mathrm{O}_{2}$ concentration to $5 \%$ with either $1 \%$ or $3 \% \mathrm{CO}_{2}$ was not an appreciable advantage over refrigerating fruit in air during the first 30 days of storage. However, after 30

Association of Official Analytical Chemists. 1970. Official methods of analysis. Assn. Official Anal. Chemists, Washington, D.C. p. 154.

Chimi, H., A. Sadik, A. Le Tutour, and M. Rahmani. 1988. Contribution à l'étude comparative des pouvoirs antioxydants dans l'huile d'olive du tyrosol de l'hydroxytyrosol, de l'acide cafeique, de l'oleuropeine et du BHT. Rev. Francaise des Corps Gras 35:339-344.

Kader, A.A., G.D. Nanos, and E.L. Kerbel. 1990. Storage potential of fresh 'Manzanillo' olives. Calif, Agr. 44:23-24.

Sciancalepore, V. and V. Longone. 1984. Polyphenol oxidase activity and browning in green olives. J. Agr. Food Chem. 32:320-321.

Siriphanic, J. and A.A. Kader. 1985. Effects of CO on total phenolics, phenylalanine ammonia lyase, and polyphenol oxidase in lettuce tissue. J. Amer. Soc. Hort. Sci. 110:249-253.

Swain, T. and W.E. Hillis. 1959. Phenolic constituents of Prunus domestica. I. Quantitative analysis of phenolic constituents. J. Sci. Food Agr. 10:63-68.

Vázquez, A., R. Maestro, and E. Graciani. 1971. Determinación de polifenoles totales en las aceitunas. Grasas y Aceites 22:371-376.

Vázquez, A., M.L. Janer, and C. Janer. 1973. Determinación de los polifenoles totales del aceite de oliva. Grasas y Aceites 24:350-357.

Woskow, M. and E.C. Maxie. 1965. Cold storage studies with olives. California Olive Assn. Annu. Tech. Rpt. 44:6-11

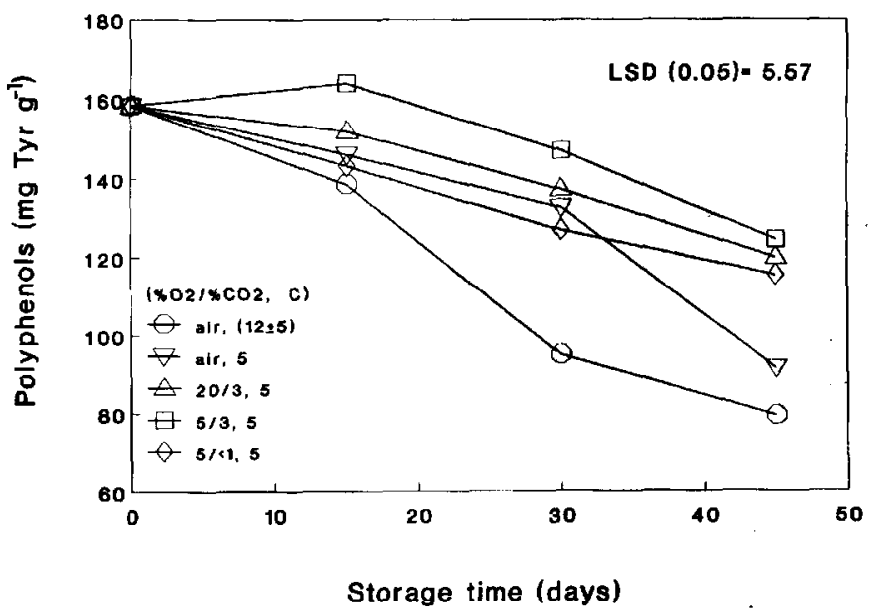

Fig. 1. Changes in polyphenol content of olives during storage in modified atmospheres or air. 